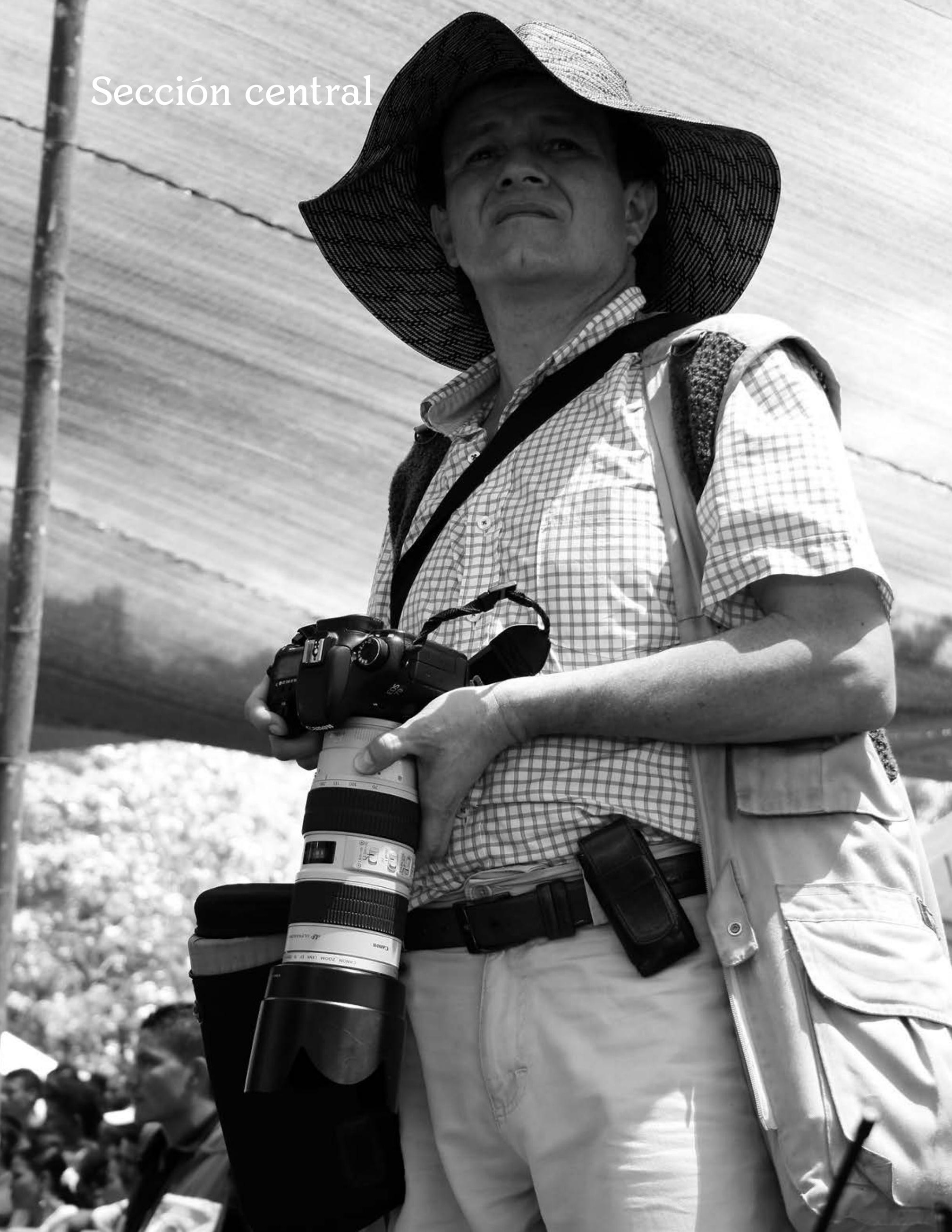




\section{Venga y mire}

\section{Artículo de investigación}

Recibido: 15 de enero de 2020

Aprobado: 7 de abril de 2020

\section{Sonia Vargas Martínez}

Universidad Nacional de Colombia, Sede Bogotá sopvargasma@unal.edu.co

Cómo citar este artículo: Vargas Martínez, Sonia (2020). Venga y mire. Estudios Artísticos: revista de investigación creadora, 7(9) pp 180-194. DOI: https://doi.org/10.14483/25009311.16237

$<$

Imagen 1. Jesús Abad Colorado (2012).

Fotografía: Carlos Mario Cano. Fuente: «https:// www.flickr.com/photos/cmcr/6949431935/in/

photolist-2hmF6fS-bA6DZZ-r9Ce8o-qupeJF-dVQcyK-dVVNwW »

\section{(c) (1)}

\section{Resumen}

En este texto exploro algunos elementos de la creciente construcción mediática del fotoperiodista colombiano Jesús Abad Colorado como una figura pública y un emergente héroe cultural, quien, con sus fotografías, ha propuesto una particular forma de memoria visual del conflicto armado colombiano. Examino cómo este posicionamiento, sumado a su larga trayectoria, autoriza su voz como testigo único para hablar del conflicto a través de las imágenes fotográficas: sus relatos orales aseguran su filiación con la imagen. Este ejercicio de narrar-contar su experiencia, hoy frecuente en distintos espacios, implica un cierto condicionamiento a la audiencia, una manera de ver imbricada con juicios morales, que en oportunidades pueden resultar limitantes tanto para la experiencia sensible que hace posible la fotografía como para sus sentidos.

\section{Palabras clave}

Visualidades; fotoperiodismo; Jesús Abad Colorado; actos del ver; guerra en Colombia 


\section{Come and Take a Look}

\section{Abstract}

In this text I explore some elements of the growing media corpus of the Colombian photojournalist Jesús Abad Colorado as a public figure and an emerging cultural hero, who, with his photographs, has proposed a particular form of visual memory of the Colombian armed conflict. I examine how this position, added to his long career, authorizes his voice as the only witness to speak of the conflict through photographic images: his oral stories ensure his affiliation with the image. This exercise of narrating-recounting his experience, that has taken place in many different spaces, implies a certain conditioning of the audience, a way of seeing intertwined with moral judgments, which on occasions can be limiting both for the sensitive experience that makes photography possible as for the senses of thar audience.

\section{Keywords}

Visualities; photojournalism; Jesús Abad Colorado; acts of seeing; war in Colombia

\section{Venez jeter un œil}

\section{Résumé}

Dans ce texte, i'explore certains éléments du corpus médiatique croissant du photojournaliste colombien Jesús Abad Colorado en tant que personnage public et héros culturel émergent, qui, avec ses photographies, a proposé une forme particulière de mémoire visuelle du conflit armé colombien. J'examine comment cette position, ajoutée à sa longue carrière, autorise sa voix comme seul témoin à parler du conflit à travers des images photographiques: ses récits oraux assurent son affiliation à l'image. Cet exercice de narration-récit de son expérience, qui a eu lieu dans de nombreux espaces différents, implique un certain conditionnement du public, une façon de voir entrelacée avec des jugements moraux, qui peuvent parfois être contraignants à la fois pour l'expérience sensible qui rend la photographie possible quant aux sens du public.

\section{Mots clés}

Visualités ; photojournalisme ; Jesús Abad Colorado ; actes de regarder ; guerre en Colombie 


\section{Venha e olhe}

\section{Resumo}

Neste texto exploro alguns elementos da crescente construção midiática do fotojornalista colombiano Jesús Abad Colorado como uma figura pública e um herói cultural emergente que, com suas fotografias, tem proposto uma forma particular de memória visual do conflito armado colombiano. Examino como este posicionamento, somado a sua longa trajetória, autoriza sua voz como a única testemunha para falar do conflito através das imagens fotográficas: seus relatos orais asseguram sua filiação com a imagem. Este exercício de narrar-contar sua experiência, hoje frequente em distintos espaços, implica um certo condicionamento à audiência, uma maneira de ver imbricada com juízos morais, que ocasionalmente podem resultar limitantes tanto para a experiência sensível que faz possível a fotografia como para seus sentidos.

\section{Palavras chave}

Visualidades; fotojornalismo; Jesús Abad Colorado; atos de ver; guerra na Colômbia.

\section{Samui kauasunchi}

\section{Maillallachiska:}

Kai runita Jesús Abad Colorado suti munakumi kauachispa parlangapa imasami pai pasaska ajai iakiikuna, sachuku pusankuna musukunata chasallata wawakuna, pai churuska paipa rimai tukuikuna ullungapa. Chasallata ruraska tukuikunata kauachingapa imasami kauasunchi Nukanchipa atun llagta Colombia sutipi. Mailla manchaspa kauachi paipa ruraikuna imasa iuiariska.

\section{Rimangapa Ministidukuna:}

Achka kauaikuna; ruraikuna kauachidur; runa chasa suti Jesús Abad Colorado; ima suraska kauai; Achka iakiikuna atun llagta Colombia sutipi. 


\section{Introducción}

Si le suena conocida la imagen de una niña mirando a través de un cristal roto, o un entierro de víctimas de un atentado de la guerrilla del ELN a un oleoducto, un cráter dejado por un bombardeo del ejército en la Operación Génesis en Riosucio, el Cristo mutilado en la iglesia de Bojayá tras el ataque de las FARC, es porque seguramente conoce estas fotografías de Jesús Abad Colorado realizadas entre 1997 y 2002. Son impactantes, movilizan emociones y opiniones, afectan e inquietan la mirada y, varias de ellas, han llegado a convertirse en íconos de la guerra en Colombia. Pero no son las únicas que ha tomado, pues en sus 27 años de labor como fotoperiodista ha construido un archivo de esta violencia imparable en el país, del cual podemos ver por lo menos 500 fotografías en la muestra El Testigo: Memorias del conflicto armado colombiano en el lente y la voz de Jesús Abad Colorado, que se encuentra expuesta desde el 20 de octubre de 2018 y estará abierta hasta el 28 de junio de 2020.

Venga y mire, paradójicamente, no es un texto donde muestro estas fotografías u otras del fotoperiodista. Casi no hay fotos. No exploro la fotografía en sí misma, no me detengo en un análisis de su iconicidad, ni hago un reconocimiento a su capacidad de ilustrar los horrores de la guerra. Aquí no exploro la fotografía de guerra pese a que esta ha impuesto históricamente y a nivel global sistemas sexuales normativizados (Gutiérrez y Resende, 2018), multiculturalismo visual (Arfuch, 2008) y un modelo particular de rostricidad (Deleuze y Guatari, 1994) como forma legítima de producción de rostros -de las víctimas-. En cambio, exploro algunos elementos de la creciente construcción mediática del fotoperiodista colombiano Jesús Abad Colorado como una figura pública y un emergente héroe cultural, quien, con sus fotografías, ha propuesto una particular forma de memoria visual del conflicto armado colombiano. A su vez, examino cómo este posicionamiento, sumado a su larga trayectoria, autoriza su voz como testigo único para hablar del conflicto a través de las imágenes fotográficas: sus relatos orales aseguran su filiación con la imagen. Este ejercicio de narrar-contar su experiencia, hoy frecuente en distintos espacios, implica un cierto condicionamiento a la audiencia, una manera de ver imbricada con juicios morales, que en oportunidades pueden resultar limitantes tanto para la experiencia sensible que hace posible la fotografía como para sus sentidos.

Con su trabajo se ha puesto de relieve el lugar de la fotografía en su dimensión restauradora, testimonial, comunicacional. Mi apuesta no consiste en hacer un cuestionamiento a Jesús Abad ni es un intento por demeritar su importante trabajo, consiste en examinar los ejercicios de mirada que construimos a su alrededor como audiencia. Es por esto que resulta importante señalar que el condicionamiento de la mirada de la audiencia, así como la construcción de la figura del artista no son exclusivos de Jesús Abad Colorado, por el contrario, resuena como eco de muchas propuestas artísticas y culturales que en el marco del posacuerdo construyen y conducen más visualidades empáticas y compasivas como efecto de la mediatización de sus discursos y sus representaciones.

Ante la proliferación de estas situaciones, urgen otras formas de abordar el quehacer artístico actual, tan interesado en el conflicto armado, que se arriesguen a descentrar el objeto artístico y el signo y se aventuren a explorar los efectos que produce. ${ }^{1}$ Para este fin me aproximo a poner de relieve los rasgos performáticos y performativos; su construcción como figura empática, casi heroica y su narración como testigo único que conducen la visualidad y la mirada, gestando la triada: imagen, memoria e imaginario.

Este examen crítico-sensible aportará al desmontaje de prácticas coloniales de saber-poder, ver-conocer, racismo, generismo y patriarcado que siguen siendo invisibilizadas y reproducidas en el campo del arte colombiano.

\footnotetext{
1 A partir de estas exploraciones busco abrir otros caminos al abordaje del arte y la memoria en el país, distintos a las perspectivas de análisis existentes hasta el momento centradas principalmente en temas como la resiliencia y la capacidad sanadora del arte (Acosta, 2017), el apoyo psicosocial al dolor y el trauma colectivo (Martínez, 2013), la posibilidad del arte como forma de activar procesos con la gente (Rubiano, 2014; Gutiérrez, 2016), las representaciones visuales de las víctimas en el arte y los análisis críticos de los discursos (Bustos, 2019; Gamboa, 2017; Roque, 2018; Yepes, 2012).
} 


\section{La construcción de la figura del fotoperiodista}

El fotógrafo de la vida (El Espectador, 13 de agosto de 2013).

No cabe duda que Jesús Abad Colorado cuenta con un amplio y merecido reconocimiento nacional e internacional debido a su trabajo y trayectoria como fotoperiodista del conflicto interno colombiano. Más allá de cuestionar dicho reconocimiento, busco poner de relieve las maneras como en torno suyo se edifica la figura del fotoperiodista como héroe cultural. Para este fin acudiré, en primer lugar, a la prensa y su diversificada forma de nombrarlo; en segundo lugar, a la muestra antológica El testigo: Memorias del conflicto armado colombiano en el lente y la voz de Jesús Abad Colorado, que recoge su trabajo fotográfico y su voz; y, en tercer lugar, a lo que el propio Jesús Abad dice de sí mismo. Estas formas de nombrarlo y de nombrarse a sí mismo devienen como prácticas de visualidad que pretenden hacer ver al fotoperiodista como figura emblemática, cuasi héroe cultural.

El fotógrafo de la guerra (El Tiempo, 5 de enero de 2003).

El fotógrafo de la guerra que exhorta a la paz (Las2orillas, 12 de octubre de 2017). Jesús Abad Colorado: desde el ángulo de la dignidad (Bitácora Eafit, 22 de septiembre de 2017). Testigo mayor de la historia nacional de la barbarie (Las2orillas, 25 de octubre de 2018).

Jesús Abad Colorado, más que un fotógrafo, un compañero de las víctimas (El Tiempo, 20 de abril de 2019).

La obra histórica de Jesús Abad Colorado (La nueva prensa, 21 de abril de 2019).

Estos encabezados brindan un panorama de las variadas formas de nombrar al fotoperiodista que sin duda se ha convertido en el más destacado del momento en Colombia. Si miramos atentamente nos daremos cuenta que existe una cierta intencionalidad por nombrarle e interpelarle desde un compromiso ético que se lee allí entre líneas. Frases como "El compañero de las víctimas" o "desde el ángulo de la dignidad" parecen reafirmar un vínculo entre el fotógrafo y la población vulnerada. Hace referencia a su postura personal, el "ángulo" aparece como forma de mirar y el lugar moral desde el cual decide fotografiar.

Es sabido que durante años Jesús Abad ha realizado una labor como activista y defensor de los Derechos Humanos al visibilizar a las personas vulneradas en el marco del conflicto armado. No obstante, los encabezados y sus contenidos más que atender al llamado de alerta y la denuncia que hace el fotoperiodista, se vuelcan en la construcción de la figura de un sujeto empático con las víctimas, con la gente "de a pie", humanitario, ético, comprometido.

Otros encabezados como "El fotógrafo de la guerra que exhorta a la paz" o "El fotógrafo de la guerra", a pesar de la mención a la guerra, paz y conflicto, no ponen en el centro del debate al conflicto armado en sí mismo, ni a las estructuras de poder sobre las que este se sustenta. Por el contrario, El fotógrafo de la guerra naturaliza la relación entre guerra y fotografía. Paradóiicamente el hacer ver al fotoperiodista como figura parece opacar al conflicto armado, el cual queda como mero telón de fondo o como una situación preexistente. Estos encabezados, junto al contenido de los artículos se convierten en una manera anecdótica de articular el relato del conflicto y no nos dejan comprender ¿Por qué hay tantas víctimas qué retratar? ¿Quiénes hicieron de las personas víctimas? ¿Por qué existe aún la fotografía de guerra? Y ¿Para qué?

\section{La obra histórica de Jesús Abad Colorado deja} ver cómo con su actual posicionamiento se le ha endilgado una parte importante en la responsabilidad de la construcción -visual- de la historia y la verdad del conflicto. Una verdad fragmentada en tanto que la fotografía es siempre recorte, codificación de la realidad, fidedignidad y verosimilitud. Estas cualidades propias de la fotografía, no han sido impedimento para que sean vistas como "la verdad" no contada del país, el espejo oscuro del pasado, la huella de la historia silenciada, deviniendo así en documento oficial del conflicto nacional. 


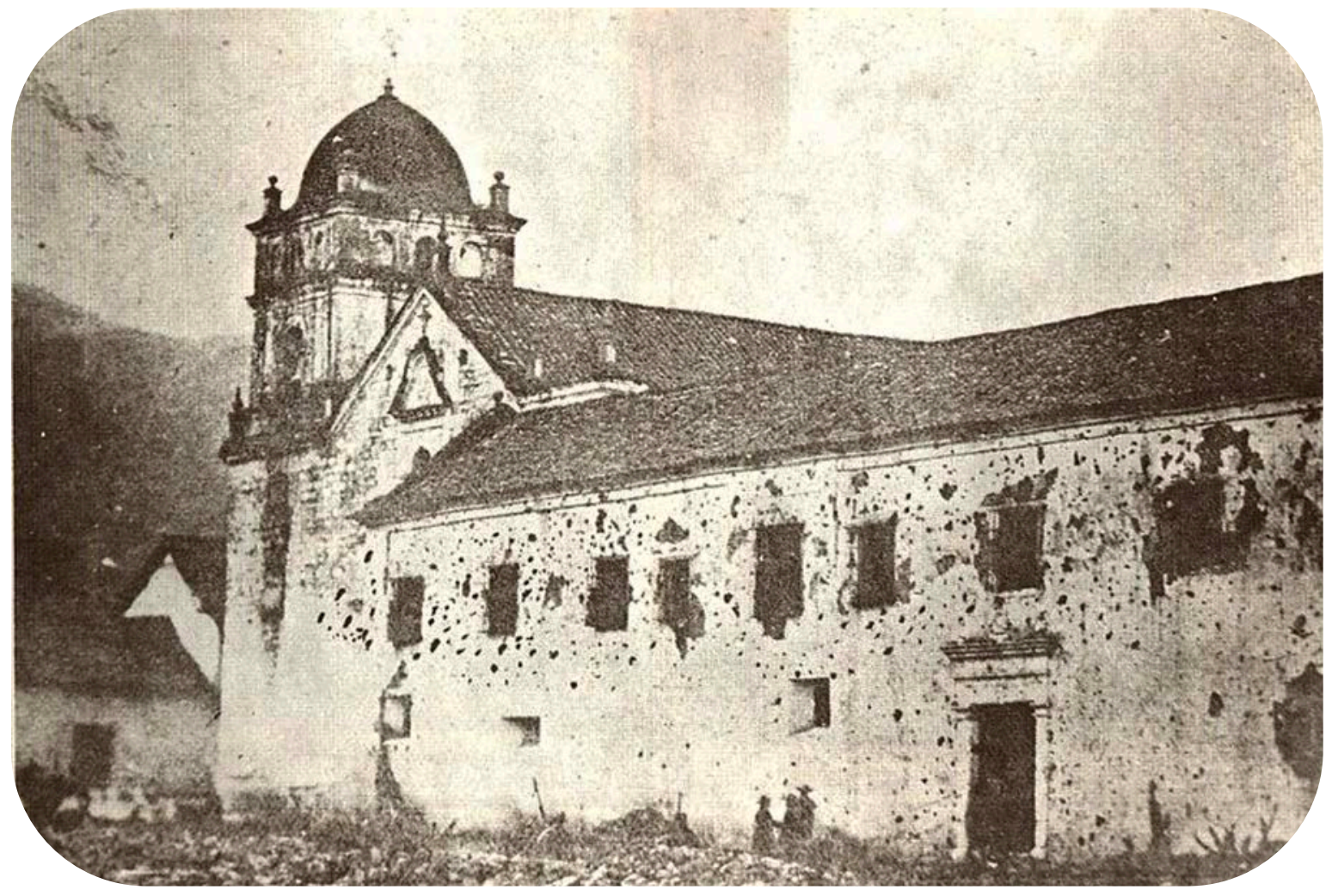

Imagen 2 Iglesia y Convento de San Agustín: Luis García Hevia (Bogotá, 1862). Copias en Albúmina. Publicadas en El Gráfico, 25 de febrero de 1911

\section{El testigo}

El testigo: Memorias del conflicto armado colombiano en el lente y la voz de Jesús Abad Colorado, es el nombre de la muestra antológica producida por la Universidad Nacional de Colombia, localizada en el Claustro de San Agustín y curada por María Belén Sáez de lbarra, ${ }_{1}^{2}$ que abrió sus puertas el 20 de octubre de 2018 y su cierre se ha postergado en tres oportunidades en el presente año, dada su amplia acogida de visitantes nacionales e internacionales.

2 La curaduría propuso una organización de las fotografías en cuatro salas que aluden a distintas dinámicas del conflicto armado. Primera, Tierra callada, desplazamiento. Segunda, No hay tinieblas que la luz no venza, desaparición forzada. La tercera, $Y$ aun asi me levantaré, violencia en las guerras civiles. Cuarta, Pongo mis manos en las tuyas, manifestaciones por la paz, desmovilizaciones y los procesos de reconstrucción de las comunidades.
Más allá de una descripción formal o de una crítica curatorial, me interesa pensar a El testigo como un montaje discursivo que también interviene en el posicionado de la figura del fotoperiodista como "Testigo mayor de la historia nacional de la barbarie", el principal y más relevante testigo del conflicto del país. Su testimonio visual de más de 500 fotografías y su testimonio oral (traducido en palabra escrita en las paredes de la muestra) constituye una de las narrativas más importantes del país, que este proceso de musealización institucionaliza.

La muestra actualiza y contribuye a la construcción de un relato de nación asociado a la guerra en Colombia, al tiempo que refuerza un lenguaje particular de la memoria ligada a la fotografía. Su repertorio visual-oral deviene en un relato con pretensiones de devenir en memoria oficial y pasar de ser un ejercicio personal a ser una memoria compartida y aceptada por la audiencia. De esta 


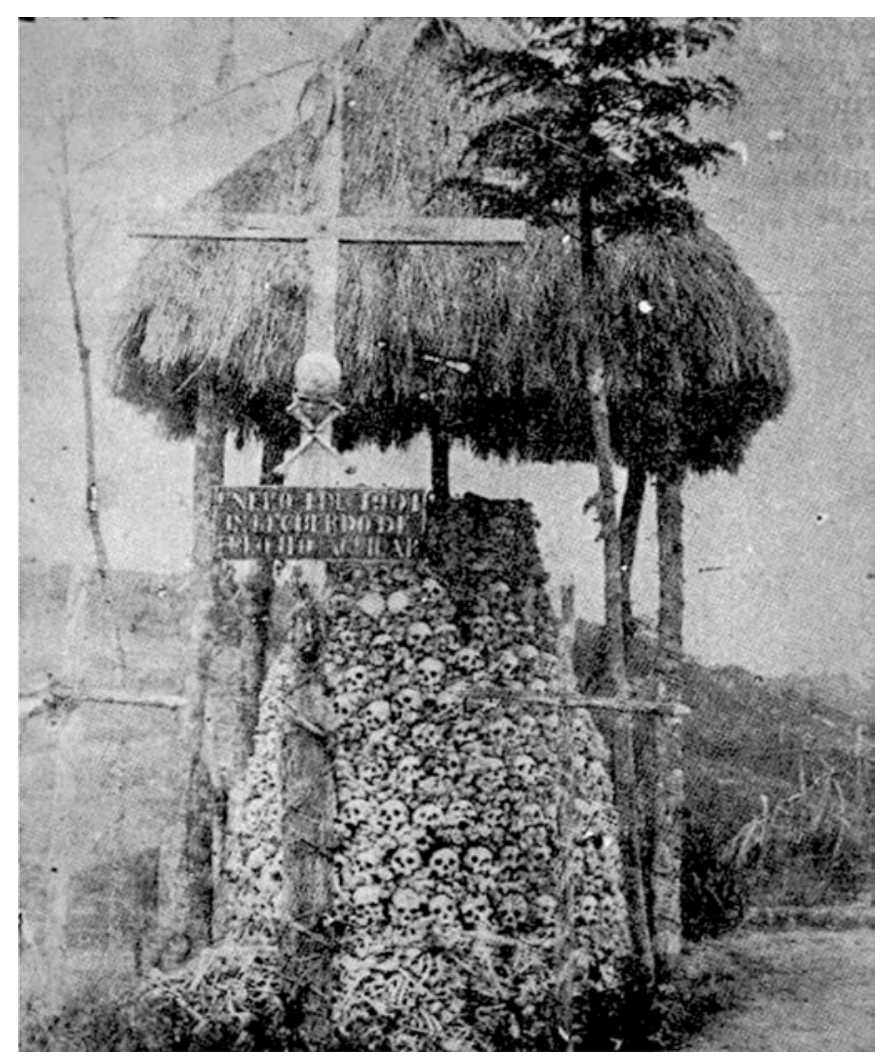

Imagen 3. Loma de los muertos. Fotografía: Amalia Ramírez de Ordoñez (Palonegro, 1901). Copia en Albúmina.

manera, se corre el riesgo de hacer ver a Jesús Abad como el principal constructor de la memoria visual del conflicto colombiano.

Sin embargo, el repertorio visual del conflicto y de la guerra en Colombia no solo es extenso, sino que está ligado a la historia misma de la fotografía en el país. No es casual que la primera fotografía impresa en Colombia, en tiempos del auge del daguerrotipo, fuese una fotografía de guerra realizada por el pintor y fotógrafo Luis García Hevia, quien registró en 1862, la llamada Batalla de San Agustín, llevada a cabo en Bogotá y que tuvo como epicentro el Templo de San Agustín, (hoy iglesia de San Agustín). Si es casual que sea el mismo lugar que acoge hoy a El testigo.

La fotografía muestra en un plano general la fachada de adobe del templo baleada, producto de la Batalla homónima adelantada por las tropas simpatizantes del entonces presidente de la república Mariano Ospina Rodríguez contra las tropas del general Tomás Cipriano de Mosquera, quien intentaba derrocarlo del poder. El ataque a la ciudad duró tres días y el templo fue expropiado por el gobierno colombiano y convertido en cuartel militar. Los Agustinos volvieron al templo en el año de 1867 y conservaron el convento hasta 1938.

Estas fotografías que registraron la batalla, operan como prueba real de la existencia de este hecho. ¿Traerlas a colación hoy acaso alerta sobre el continuum de guerras y el conflicto nacional o sobre el lugar, como constructores de memoria, de quienes hicieron su registro?

Estas fotografías permiten hoy imaginar pese a todo (tomando prestada la famosa expresión de Didi Huberman). También permiten establecer una especie de ADN de la fotografía y el conflicto o 
la guerra en Colombia. ADN en tanto que la fotografía de guerra reproduce, transforma y actualiza los códigos y signos heredados. No obstante, la mayor preocupación sigue siendo que la fotografía sustituya al acontecimiento hasta el punto de estructurar la memoria más eficazmente que la comprensión (Butler, 2009, p. 105), es decir que reaccionemos ante la fotografía y no ante el contexto. En cualquier caso, estas imágenes nos invitan a crear fugas diacrónicas que conectan historia, memoria, práctica fotográfica, luchas por el significado y sentido del presente.

\section{De la mirada sensible}

Las fotografías son pulsaciones del alma (Al Día, mayo 31 de 2019).

Jesús Abad se reconoce así mismo como un sujeto sensible, señala que posee una mirada femenina, que asocia a su lado sensible, y que le ha permitido construir formal y conceptualmente las fotografías que conocemos hoy (Colorado, 6 de junio de 2019). No obstante, el nombrar una mirada femenina o asociar feminidad a sensibilidad tiene complejas implicaciones que no podemos pasar por alto, como naturalizar la existencia de formas de mirar propia de las mujeres, como si se tratase de una cualidad biológica y no el resultado de una construcción cultural que históricamente ha regulado ciertos comportamientos a cada cuerpo.

No obstante, que este fotoperiodista reconozca lo femenino en sí podría llegar a ser un gesto provocador para un medio machista como lo es el fotoperiodismo en Colombia. Resultaría incluso interesante esta afirmación en tanto postura estratégica que contribuyera a la transformación de la práctica del fotoperiodismo, reconociendo que ha sido tradicionalmente masculina y masculinizada, a partir de la cual se han reforzado ideas e ideales sobre los hombres y el riesgo, el coraje, el valor, la temeridad o la exposición, que en resumidas cuentas refieren a la construcción glorificada y heroica del fotógrafo de guerra. ${ }^{3}$

3 Los más reconocidos fotógrafos del país han sido hombres, la mayoría de ellos oriundos de Antioquia, un departamento donde a inicios de siglo XX los procesos de industrialización y modernización dieron pie a los más destacados estudios fotográficos del país. Una larga lista de reconocidos
Paradójicamente o no, el lugar de las mujeres que obturan la cámara es tan antiguo como la llegada de la fotografía al país. Basta con señalar que la primera fotografía realizada por una mujer -de la que se tenga registro- fue una fotografía de guerra realizada por Amalia Ramírez de Ordoñez, quien en 1900 registró la llamada Loma de los muertos u Osario de Palonegro, un monumento erigido en el cementerio de Bucaramanga, tras una de las más grandes batallas de la Guerra de los Mil Días, donde las confrontaciones entre conservadores y liberales dejaron como resultado 4.300 muertos y miles de heridos. Con los restos de las víctimas se realizó en forma piramidal una escena dantesca en la que se dispusieron las calaveras y otros restos óseos, acompañadas con un letrero que decía: "Año de 1901, en recuerdo de..."

Esta es la fotografía de la ruina humana, de la historia de la guerra o la guerra histórica, es la fotografía convertida en dato. La figura de la fotógrafa, ni heroína ni emblemática, continúa hoy en anonimato. Esta situación nos alerta sobre el lugar de las mujeres fotoperiodistas en Colombia, nombres como: Patricia Rincón, Natalia Botero, Eliana Aponte, Lucy Castro resaltan entre muchas otras que han resquebrajado el mandato que dicta que las mujeres en Colombia son educadas para ser vistas.

\section{El fotoperiodista como héroe cultural}

Históricamente, el héroe ha sido un arquetipo cultural dotado de sentido simbólico como: la unión de comunidades, modos de vida, formas de obrar. En él se sintetizan cualidades como la valentía, temeridad y la asechanza de la muerte y valores morales judeocristianos como el dolor, el sacrificio y el sufrimiento. Es un ser que transita entre la humanidad y la deidad al portar características que

\footnotetext{
fotógrafos como Demetrio Paredes, Fermín Isaza, Melintón Rodríguez, Beniamín de la Calle, entre otros, iniciaron un uso político de la fotografía, muchos de ellos abanderaban posturas radicalistas y liberales. Este escenario dio paso a la reportería gráfica, con personajes como Sadi González, Carlos Caicedo, Leo Matiz, Ignacio Gaitán y, por supuesto, el lugar de los medios impresos desde el Papel Periódico llustrado, El Gráfico, Cromos, entre otros. De ahí el potencial político y referencial que la imagen fotográfica guarda hasta nuestros días.
} 
lo acercan a lo humano, al tiempo que logra trascenderlo (Cardona, 2006).

En el actual contexto colombiano construimos héroes para dotar de sentido nuestro enrarecido mundo enmarcado en coyunturas políticas y sociales. La figura heroica del fotoperiodista sirve para crear lazos y consensos, para generar empatía y sentido de solidaridad, para encarnar los ideales y valores percibidos como perdidos. Es un referente cultural en medio de la crisis de polarización y división política-ideológica que encierra el país.

La historiadora colombiana Patricia Cardona Zuluaga, propone una tipología del héroe para señalar los acentos particulares y singularidades de esta figura universalizada. Siguiendo a la autora, el héroe mítico es quien funda la ley, la construye para dar orden, por su parte el héroe trágico es quien defiende su pueblo y padece, el héroe novelesco, como El Quijote de Cervantes o el Ulises de James Joyce, es un personaje solitario que lucha contra sus propios demonios, o el superhéroe de los cómics y el cine de Hollywood un personaje entre sobrenatural y con vicisitudes mundanales (Cardona, 2006). El fotoperiodista como figura heroica no necesariamente encarna a cabalidad alguno de los héroes descritos por la autora, pero sí porta matices de uno y otro; seguramente es con el héroe trágico donde encuentra mayor filiación. Comparte características descritas por la historiadora como recorrer el mundo y explorarlo, no ser estático y dejar que sea el movimiento el que le da sentido de devenir, también comparte el ser vulnerable, sufrir el trauma social, ser épico y político, en él se encarnan los ideales morales, es reconocido por las colectividades a quienes recuerda y alerta sobre la oscuridad y el peligro, establece relaciones con el pasado caótico.

Resaltan sus hazañas para realizar los cubrimientos de hechos, el recorrer los más complicados trayectos del país por vía aérea, fluvial o caminando para llegar a los rincones más apartados, en medio de tensiones y ataques entre el ejército nacional y los grupos insurgentes. Su figura heroica le ha permitido ganar el respaldo de organizaciones y figuras de autoridad en zonas de alta tensión, que ponen a su disposición los medios necesarios (contactos, helicópteros, lanchas, entre otros) para realizar el cubrimiento personal de los hechos en momentos y lugares impensables para muchos.

Este fotoperiodista se consolida como figura heroica en medio de distintas luchas por la memoria de la guerra en el país, que demandan la necesidad de visibilizar a las víctimas y sus relatos. Es en medio de diversos empeños institucionales por construir la memoria de la guerra, que las fotografías de Jesús Abad adquieren una importante visibilidad, al punto que pareciera que con estas se instaura un ordenamiento particular de lo visual.

\section{La voz que deviene imagen}

Yo soy de los que dice que una imagen no vale más que mil palabras. Soy de los que dice que esas imágenes necesitan de muchas palabras. Es un ejercicio ético y estético y un compromiso con la verdad. Jesús Abad Colorado (enero 30 de 2019). ${ }^{4}$

La voz de Jesús Abad se hace escuchar para completar lo que se nos escapa de la imagen. A veces para complementarla y situarla, otras veces para señalar que la realidad del conflicto es más compleja, es de zonas grises. Ha sido frecuente escuchar su voz en la radio y la televisión, así como en distintas universidades del país donde realiza charlas, talleres y conversatorios. ${ }^{5}$ La intención aquí es poner de relieve esta particularidad de hablar con y sobre las fotografías, centrando los actos del habla de este fotoperiodista, una aproximación a la iconicidad performativa de su palabra y a los posibles efectos producidos en la audiencia. Al tiempo que la fotografía refuerza la "verdad", constata el hecho y lo hace creíble.

Cada vez que tiene oportunidad el fotoperiodista narra y testimonia sus fotografías; brinda información de las y los protagonistas, sus nombres, edades, fechas y horas de los hechos, recrea anécdotas y experiencias, nos cuenta el durante y

\footnotetext{
4 Todos los extractos aquí citados fueron tomados de la entrevista realizada por Santiago A. de Narváez el 30 de enero de 2019, en la página de Pacifista. «https://pacifista.tv/notas/ jesus-abad-colorado-testigo-fotografia-periodismo-entrevista/» 5 Las más recientes son: Una Mirada a la vida profunda, charla realizada en la Universidad Central en febrero de 2019, y Política visual de la memoria, taller realizado en la Universidad Nacional de Colombia en junio de 2019.
} 
después de la imagen. También reclama dignificación y respeto para las víctimas, cuestiona el papel de la clase dirigente, de la clase política, de la iglesia, de la educación.

Estos ejercicios de contar/narrar las imágenes han sido recurrentes en su trayectoria profesional y evidencian la relación dialéctica entre hablar acerca de las fotografías y que las fotografías hablen.

Palabra e imagen se articulan en un contar/mostrar simultáneo que se interconectan para la construcción de la memoria. Al respecto, la crítica cultural Leonor Arfuch señala que "estos dos órdenes (verbal y visual) activan, crean la memoria, su potencialidad de iluminar zonas dormidas, agazapadas, negadas, reprimidas" (Arfuch, 2006).

El narrador/relator recrea en palabras una historia que a su vez está construida en la imagen fotográfica. Con este ejercicio se condiciona a la audiencia una forma de ver-leer las imágenes, se anticipa y determina la manera cómo vemos lo que vemos, deviniendo en una manera de constitución del ver.

Para desarrollar esta proposición, resulta oportuno traer a colación la filosofía del lenguaje, particularmente el planteamiento de John Austin sobre los actos del habla, según el cual los enunciados lingüísticos no afirman o nombran algo, sino que estos realizan acciones. La falacia descriptiva, nombrada por este autor, es pensar que la palabra describe el mundo, por el contrario, con el lenguaje se construyen ciertas acciones. La unidad básica de la comunicación no son entonces las palabras o las frases sino los actos del habla. De esta manera los enunciados devienen performativos, en tanto su capacidad de realización de la acción. Con su clásico ejemplo del bautizo y la boda, Austin señala el poder performativo de los enunciados, en este caso el cura como figura de autoridad, al pronunciar el nombre y apellido (acto del habla) del niño/ niña o declarar marido y mujer, en el caso de la boda, realiza las acciones que tendrán implicaciones en la vida material y simbólica de los sujetos.

Los actos del habla devienen formulaciones, pero lo que hace que sean performativos, y no solo lingüísticos, son el carácter institucional y social. Así, es el acto social, la escenografía de lo social (la iglesia en este caso), la comunidad, la persona que la representa como figura de autoridad y el contexto son determinantes de la acción y son constitutivos de la realidad. Para el autor, lo interesante es el valor de verdad que adquieren las emisiones lingüísticas.

Posteriormente, Austin desarrollaría una división constituida por tres tipos de actos de habla: locutivo, ilocutivo y perlocutivo, con la intención de demostrar que hablar es siempre actuar. Los actos locutorios, corresponden con lo que decimos, los ilocutivo se refieren a la intención de lo que decimos, el objetivo o propósito del hablante y los perlocutivo son los efectos que produce lo que decimos a la audiencia, lo que el ilocutivo produce. $^{6}$

A este respecto, cuando el fotoperiodista dice: "mis fotografías son lo que apenas yo he visto", "son un ejercicio ético y estético y un compromiso con la verdad", cuyo propósito es "crear un testimonio contra el olvido", no solo está describiendo o afirmando cómo es su trabajo, con este acto ilocutivo está modificando la situación al legitimarla. En esos actos del habla pone de manifiesto las maneras como sus fotografías, independientemente del motivo, pasan de ser codificaciones de una realidad, artefactos bidimensionales, a ser acción en el presente. Al enunciar que sus fotografías "son un ejercicio ético... y crean testimonio..." propone que sus fotografías ahora acción ética, construyen verdad y testimonio en un presente. Cada vez que veamos sus fotografías pensaremos en su cualidad de acción ética, que construye

\footnotetext{
6 El filósofo John Searle, dará continuidad al estudio del lenguaje desarrollando nuevas aportaciones para señalar que el uso de pronombres personales, frases nominales y nombres propios, así como predicados usados por el emisor, no pueden entenderse en su mero contenido semántico sino en su relación con el acto ilocutivo. Por su parte Austin, más que detectar si los actos del habla son falsos o verdaderos, buscará examinar si los actos son conseguidos o fallidos. Así, para que un acto ilocutivo sea conseguido, se requieren algunas condiciones como, por ejemplo, que la persona que ejecuta el acto cuente con autoridad para realizarlo, que quien efectúa el acto debe creer en lo que dice y estar comprometido con ciertas intenciones. El efecto perlocutivo es su acción sobre las creencias, actitudes y conductas sobre la audiencia. Con este se puede convencer, inspirar, persuadir al dar consejos, asustar, solicitar o pedir que hagan algo.
} 
permanentemente la verdad, de ahí su dimensión performativa. $^{7}$

Para constatar si estos actos del habla son o no fallidos, basta con ver el reconocimiento positivo de la audiencia, el cual posibilita este éxito. De alguna manera para los medios y para la audiencia se ha instaurado una opinión compartida sobre la verdad y la ética de sus fotografías, evidenciada en la destacada recepción de su trabajo.

\section{Escenificación y performance}

Estos actos del habla se efectúan en la televisión y la radio, pero sin duda donde logran tener más potencia es principalmente en las universidades donde se hacen charlas, talleres y conversatorios. Las locaciones suelen ser más bien austeras, al tratarse de auditorios y salas para eventos. La escenificación se construye al organizar hacia el centro de la mirada al fotoperiodista-narrador y a su alrededor la audiencia. De esta manera se posibilita al hablante interiorizar lo que dice mientras muestra sus fotografías proyectadas en video beam, al tiempo que permite a la audiencia disponerse en el ejercicio de ver-escuchar.

La escenificación permite la activación del dispositivo: palabra-oído-mirada y con él, el despliegue performático del fotoperiodista. La potencia de esta performance consiste en el poder de su voz para narrar las imágenes con una diversidad de emociones y estados anímicos (desde tranquilidad, calma, nostalgia, dolor, impotencia o rabia) y con un tono que varía según estos estados; usualmente inicia con su historia de vida, su familia afectada por la violencia, su trayectoria en el medio, nos cuenta de las personas fotografiadas que conoce, que visita con frecuencia, y que ha perdido de vista, las cronologías, las fechas, las situaciones y las hazañas, información para la construcción oral y visual de la memoria. El carácter ritualístico de repetir una y otra vez en el tiempo la narrativa,

$7 \quad$ No podemos ignorar la agencia de la fotografía, por sí misma construye realidad del mundo, participa en la construcción visual de las víctimas y de los victimarios, de la guerra y el horror en general, con su ejercicio de exposición, intertextualidad permanente y reiteración de códigos, la fotografía es también performativa. tiene como finalidad que esta perdure en la memoria colectiva. ${ }^{8}$

Al tiempo, la audiencia concede importancia y admiración al fotógrafo que da un rostro, un nombre, una historia a las víctimas. Sus miradas y escucha atenta hacen posible la acción performática.

La función de este fotoperiodista como un cuasi héroe cultural en el contexto actual colombiano es la de participar de la construcción de la memoria nacional, en medio de la urgencia que trae consigo la crisis de la paz. La repetición de su acción performática (charla/conversatorio/taller) cumple el objetivo de volver a poner en escena un repertorio de significados socialmente compartidos y establecidos de antemano: el dolor, la indignación y la conmiseración.

\section{De la mirada moral}

Las narraciones no solo permiten mantener vivas a las fotografías en el tiempo, también movilizan y producen efectos en la audiencia. Como señalé anteriormente, estos efectos de los actos del habla son denominados por Austin como actos perlocutivos, cuyo efecto es su acción sobre las creencias, conductas o actitudes de la audiencia, se encargan de influir sobre sus sentimientos, persuadirles para que hagan algo, crean en algo, se puede convencer, aconsejar, asustar, pedir, entre otros.

Más que autoritarios o arbitrarios los actos del habla del fotoperiodista potencialmente hacen ver y hacen actuar a la audiencia. Logra intervenir en sus opiniones mediante el establecimiento de vínculos morales, mediados también por la fotografía. De esta manera, el dispositivo palabra-oído-mirada participa en procesos de subjetivación de la audiencia, construyendo una forma de ver particular, como veremos a continuación.

Al respecto de El testigo, Jesús Abad dice:

8 Maurice Halbwachs, pionero en el tema, señala que la memoria puede ser asumida como parte de esta construcción de comunidad; tiene un papel cohesivo. Así, la memoria individual deja de ser potestad del individuo (lo que es capaz de recordar) y pasa a ser una parte de la memoria del grupo. 
Le estoy haciendo un llamado a este país y a esos analistas que saben ver la guerra desde una cabina de radio. A esos analistas que la ven desde un aula universitaria: por favor, vengan, caminen con calma.

...háganlo en silencio, como lo están haciendo miles de personas que cuando entran a estas salas, lo hacen con respeto. Y ese respeto se expresa no solamente con el silencio sino con la calma y la lentitud, como asistiendo -no quiero utilizar la palabra funeral, no la quiero utilizar- pero con la actitud de mirar nuestro propio rostro.

Con estas frases logra persuadirnos, independientemente de si somos analistas o académicos, la frase toca a todo sujeto que ve la guerra desde un afuera. Con esa invitación consigue que pensemos en nuestra responsabilidad con el país y con el pasado. La frase también supone que ir a la muestra es una forma o vía de "estar" o "saber" de la realidad de la guerra, así se establece una relación entre el ver como equivalente del conocer. En este sentido, ir a la exposición garantizaría conocer la guerra al tiempo que nuestro compromiso ético se realizaría en verla.

En las charlas, conversatorios y talleres casi siempre las personas felicitan y agradecen a Jesús Abad por mostrarles "la verdad", manifiestan que mediante la observación de las fotografías lograron "conocer" una realidad del país, que de otra forma no conocerían.

Esta relación ver-conocer implica un ejercicio de visualidad que entiende a la fotografía como realidad y no como codificación de esta, la cual conduce a una forma de ver particular o una mirada moral que intenta hacerse pasar por general y hasta universal. En otras palabras, sus fotografías no marcan en sí mismas un antes o un después de la guerra, tampoco logran garantizar su completa comprensión, brindan una imagen parcial de los efectos de la guerra como el dolor y la catástrofe, a la vez que nos muestran sus decisiones compositivas y la escogencia de relatos específicos -heteronormados y familísticos- del conflicto.

Continuando con la frase arriba expuesta, nos percatamos que nos indica cómo debemos realizar el recorrido: "calma" y "silencio" lo que equipara a respeto. Como audiencia corporalizamos este comportamiento en espacios exhibitivos como los museos, al tratarse de un código cultural impuesto que dispone el cuerpo quieto a favor de la expansión de los sentidos, principalmente el de la vista para dar paso a la contemplación y la admiración del objeto expuesto. Esta forma de corporalizar el estar-mirar es propio de las iglesias católicas.

En El testigo esta situación acontece como habitus y por solicitud del fotoperiodista. Sin embargo, no podemos negar que a diferencia de cualquier muestra, en esta se presenta una cierta solemnidad litúrgica propia de la iglesia católica en tanto forma de ritual y de conmemoración. Ahí, no muy distinto al relato cristiano, se conmemora el dolor y el sufrimiento, el sacrificio, la vida y la muerte, que pretende transformar a la audiencia en actores morales. El cambio de audiencia en actor moral está marcado por la conmoción y la conmiseración, en este caso despertados por las imágenes del conflicto, pero también por sentir empatía con las víctimas, ira por los perpetradores de los hechos violentos, entre otros. De esta manera se despierta en la audiencia una carga afectiva y un impacto corporal, una mirada, que debiendo ser ética declina en una mirada moral dada la reiteración y el direccionamiento (verbal-visual) del trauma social.

Los actos del ver-escuchar de la audiencia y su conmiseración devienen como procesos de subjetivación. Esta mirada particular, mediada por una moral cristiana, actúa como técnica disciplinaria que busca organizar nuestro mundo y direccionar nuestra conducta. En medio de esta economía moral se corre el riesgo de producir subjetividades que sean capaces de vivir con la barbarie y las injusticias propias del capitalismo contemporáneo. Así, la empatía como mediación fracasa y la voluntad de superar el pasado se estanca. Esta carga colonial de la mirada es perpetuada en el presente.

Frases como: "Si no han ido nunca a ponerse en los zapatos y la piel de las personas afectadas por la violencia, pasen por este espacio" "¿Dónde estábamos cuando pasó todo esto?", "cuanta falta nos hace llorar a nuestros muertos" o "sería cínico si uno saliera de esta exposición y no se afectara", develan el compromiso moral que supuestamente necesitamos adquirir. De esta manera, El testigo se convierte en la posibilidad de ponernos en el lugar del otro, específicamente de su sufrimiento. "Si no 
ha ido nunca" resuena como una invitación y a la vez un reclamo a la audiencia citadina y alejada del núcleo de la guerra, así, nuestra posibilidad como ciudadanos citadinos sería la responsabilidad moral del ver-oír las fotografías de la guerra. Esta respuesta se ve reflejada en la asistencia a la muestra, que en menos de seis meses superó el record de 450.000 visitas. ${ }^{9}$ No solo influye sobre nuestros pensamientos, también despierta un sentimiento de auto culpabilidad por desconocer el conflicto o un compromiso moral de acercarnos a las víctimas y su realidad codificada en imagen como garantía. Las fotografías median entre el pasado del conflicto (no resuelto) y el presente, entre la distancia espacial, temporal y geográfica, entre las víctimas y nosotros, a fin de cuentas, la distancia entre realidades distanciadas y distantes.

Las fotografías exponen un claro repertorio cristiano. Series como Mata que Dios perdona, ganadora del Premio Nacional de Fotografía 2018 otorgado por el Ministerio de Cultura, muestran a uniformados combatientes en relación o portando en su indumentaria, objetos e imágenes religiosas que operan como punctum bartheano. Esta serie fue expuesta bajo el mismo nombre en el Centro Cultural Quinta Teresa de Cúcuta en 2019. Las referencias iconográficas también están presentes en su más reciente documental: El testigo: Caín y Abel de 2007 realizado por Kate Horne, disponible en la plataforma de Netflix, donde alude a la idea bíblica del hombre que mata a su propio hermano.

En todos estos casos existe una referencia a la imaginería católica, la cual es dada en la representación de códigos y signos conocidos, imágenes mentales archivadas que aporta a la construcción de un manierismo estético-bélico-cristiano. Este repertorio visual recrea actualiza y amplifica el dolor propio de la tradición mártir cristiana a una versión contextualizada en las fotografías al mostrar lo bueno y lo malo, reforzando imaginarios y valores cristianos. De su parte, la mirada moral de la audiencia, que deviene como efecto de un proceso de subjetivación arriba expuesto, determina

9 Han asistido víctimas del conflicto armado, algunas de ellas fueron retratadas en las fotografías expuestas, el expresidente Juan Manuel Santos, el actual presidente Iván Duque, así como figuras militares y el mismo ex líder guerrillero de las FARC, Rodrigo Londoño, alias Timochenko. su éxito. Esta mirada, aporta a la aceptación de la fotografía de guerra como verdad al tiempo que reafirma dichos valores, en una suerte de continuidad de dicha tradición colonial.

\section{El derecho de mirar (a modo de cierre)}

Venga y mire, es una invitación a reflexionar sobre los ejercicios de poder que implican los actos del habla y los actos del ver como formas programadas y performadas. Una invitación a pensar ¿De qué manera esta forma hegemónica del ver ayuda a la superación del pasado del conflicto?, ¿qué tanto la afectación de la audiencia aporta a la trasformación de la cultura?, ¿existe acaso una efectividad y una potencia en esa forma de "comprensión" de la realidad?, ¿qué implicaciones deja a nuestra subjetividad ser actores morales?

Con este texto busco abrir el debate de cómo la conmiseración de la mirada presente en experiencias como la expuesta aquí, habita la colonialidad del sentir, mediando la experiencia de la audiencia, presuponiendo un repertorio de respuestas "normales" y, en consecuencia, propiciando determinadas formas de subjetivación.

Necesitamos que la mirada sea una práctica ética de resistencia y una posibilidad política de existencia. Apelar al derecho de mirar, en términos de Nicolás Mirzoeff, es construir actos del ver desobedientes, capaces de dislocar e instar desacuerdos con lo establecido, desidentificaciones con los modelos impuestos, con el poder y la dominación, para otras formaciones posibles de sujetos (Mierzoeff, 2011). El derecho de mirar no es una responsabilidad exclusiva de los artistas, sino una posibilidad para la audiencia de articulación a la práctica crítica de descolonización de la mirada. Es por esto que necesitamos visualidades disímiles comprometidas con la producción ética de memorias incluyentes, que aporten a la construcción de mundos más justos (Walsh, 2002).

Las políticas de visión, abrirán paso a la desnaturalización de las estructuras que determinan el campo visual, de paso nos ayudarán a complejizar las formas del ver, tan a menudo domesticadas. 


\section{Referencias}

Acosta, P. (2017). Acerca de los procesos de reparación en obras performativas, en Revista Pensamiento, Palabra y Obra, 17, pp 78-93."https://doi.org/10.17227/ppo. num17-4406"

Arfuch, L. (2006). "Las subjetividades en la era de la imagen: de la responsabilidad de la mirada", en Dussel, Inés y Gutiérrez, Daniela (Comp.), Educar la mirada. Políticas y pedagogías de la imagen. Buenos Aires: Editorial Manantial.

(2008). "Presencias en imágenes (de guerra)" e "Imaginar pese a todo", en Crítica cultural, entre política y poética. Argentina: Fondo de cultura económica.

Austin, J. (1982). Cómo hacer cosas con palabras. Paidós: Palabras y acciones.

Cardona Zuluaga, P. (2006). Del héroe mítico al héroe mediático. Las categorías heroicas: Héroe, tiempo y acción, en Revista Universidad Eafit, 42(144), pp. 51-68.

Butler, J. (2009). “Capítulo 2. La tortura y la ética de la fotografía: pensar con Sontag", en Marcos de guerra, las vidas lloradas, Barcelona: Paidós.

Bustos, M. (2019). Reflexiones sobre el monumento como componente de la reparación integral y territorio de la memoria. El caso colombiano. [Texto inédito].

Deleuze, G., y Guattari, F (1994). Mil mesetas: capitalismo y esquizofrenia. Valencia: Pretextos.

Fischer-Lichte, E. (2011). Estética de lo performativo. Madrid: Abada.

Gamboa, A. (2017). "Víctimas del arte", en Ensayos sobre arte contemporáneo en Colombia. Premio Nacional de Crítica (12). Bogotá: Ministerio de Cultura.

Gómez, P. P. (ed.) (2018). Aprender, crear, sanar: estudios artísticos en perspectiva decolonial. Bogotá: Editorial Universidad Distrital Francisco José de Caldas.

Gutiérrez, C., y Resende, B. (2018). La violencia del ojo: cuerpo, fotografía y literatura, en Graphos: revista da Pós-Graduação em letras, 20(2), pp 25-42. DOI: https://doi. org/10.22478/ufpb.1516-1536.2018v20n2.44123. "https:// doi.org/10.22478/ufpb.1516-1536.2018v20n2.44123"
Gutiérrez, D. (2016). Ejercicios del cuidado, a propósito de La Piel de la Memoria. (Tesis para optar el título de Doctor en Historia del Arte). México: Universidad Nacional Autónoma de México.

Huberman, D. (2004). "Imágenes pese a todo", en Imágenes pese a todo, memoria visual del Holocausto. Barcelona: Paidós.

Mirzoeff, N. (2011). The Right to Look, en Critical Inquiry, 37(3), pp. 473-496. "https://doi.org/10.1086/659354"

Roque Romero, A. (2018). Arte público y políticas culturales en el posconflicto: potencias, retos y límites. Calle 14 Revista de investigación en el campo del arte, 13(24), 360375. "https://doi.org/10.14483/21450706.13531"

Rubiano, E. (2014). Arte, Memoria y Participación ¿Dónde están los desaparecidos?, en Hallazgos, 12(23), pp. 31-48 "https://doi.org/10.15332/s1794-3841.2015.0023.02"

Walsh, C; Schiwy, F., y Castro-Gómez, S. (2002). Indisciplinar las ciencias sociales. Geopolíticas del conocimiento y colonialidad del poder: perspectivas desde lo andino. Quito: Universidad Andina Simón Bolívar.

\section{Webgrafía}

«https://www.las2orillas.co/jesus-abad-colorado-fotografo-de-la-guerra-que-exhorta-la-paz/»

«https://bitacora.eafit.edu.co/

jesus-abad-colorado-desde-el-angulo-de-la-dignidad/»

«https://www.las2orillas.co/jesus-abad-colorado-testigo-mayor-de-la-historia-nacional-de-la-barbarie/»

«https://www.eltiempo.com/cultura/arte-y-teatro/jesus-abad-colorado-el-fotografo-de-las-victimas-en-colombia-317176»

«https://lanuevaprensa.com.co/component/k2/la-obra-historica-de-jesus-abad-colorado»«https://www.eltiempo. com/archivo/documento/MAM-988875»

«https://pacifista.tv/notas/jesus-abad-colorado-testigo-fotografia-periodismo-entrevista/» 